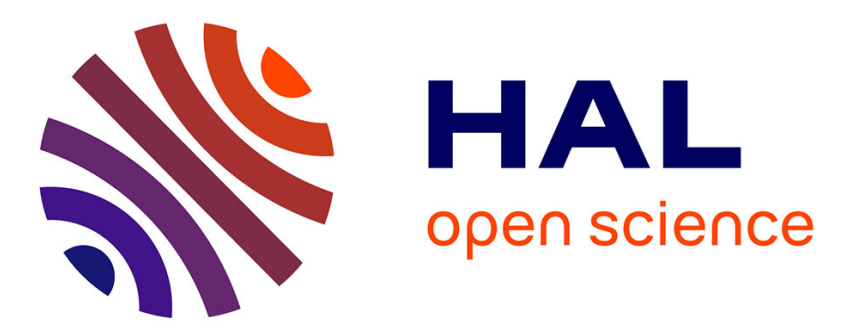

\title{
Aminoglycoside-resistant staphylococci in Greece: prevalence and resistance mechanisms
}

\author{
A. Liakopoulos, A. Foka, S. Vourli, L. Zerva, F. Tsiapara, E. Protonotariou,
} Z. Dailiana, M. Economou, E. Papoutsidou, C. Koutsia-Carouzou, et al.

\section{- To cite this version:}

A. Liakopoulos, A. Foka, S. Vourli, L. Zerva, F. Tsiapara, et al.. Aminoglycoside-resistant staphylococci in Greece: prevalence and resistance mechanisms. European Journal of Clinical Microbiology and Infectious Diseases, 2011, 30 (5), pp.701-705. 10.1007/s10096-010-1132-7 . hal-00657696

\section{HAL Id: hal-00657696 https://hal.science/hal-00657696}

Submitted on 9 Jan 2012

HAL is a multi-disciplinary open access archive for the deposit and dissemination of scientific research documents, whether they are published or not. The documents may come from teaching and research institutions in France or abroad, or from public or private research centers.
L'archive ouverte pluridisciplinaire HAL, est destinée au dépôt et à la diffusion de documents scientifiques de niveau recherche, publiés ou non, émanant des établissements d'enseignement et de recherche français ou étrangers, des laboratoires publics ou privés. 


\section{Aminoglycoside-resistant staphylococci in Greece: prevalence and resistance}

mechanisms

A. Liakopoulos ${ }^{1}$, A. Foka ${ }^{2}$, S. Vourli ${ }^{3}$, L. Zerva ${ }^{3}$, F. Tsiapara ${ }^{4}$, E. Protonotariou ${ }^{4}$, Z. Dailiana ${ }^{5}$, M. Economou ${ }^{6}$, E. Papoutsidou ${ }^{6}$, C. Koutsia-Carouzou ${ }^{6}$, E. D.Anastassiou ${ }^{2}$, E. Diza ${ }^{4}$, E. Zintzaras ${ }^{7}$, I. Spiliopoulou ${ }^{2}$, E. Petinaki ${ }^{1}$

${ }^{1}$ Department of Microbiology, University Hospital of Larissa, Greece

${ }^{2}$ Department of Microbiology, School of Medicine, University of Patras, Patras

${ }^{3}$ Department of Microbiology, ATTIKON University General Hospital, Athens

${ }^{4}$ Department of Microbiology, AHEPA University Hospital, Thessaloniki ${ }^{5}$ Department of Orthopaedics, University Hospital of Larissa, Greece

${ }^{6}$ Department of Microbiology, General Hospital 'Asclepeion', Voula, Athens

${ }^{7}$ Department of Biomathematics, School of Medicine, University of Thessaly, Larissa

Corresponding author: Dr. E. Petinaki, MD

Associate Professor,

Department of Microbiology,

Medical School,

Biopolis, Larissa, Greece

Tel: $+30-2413502517$

Fax: $+30-2413502535$

e-mail: petinaki@med.uth.gr 


\begin{abstract}
To determine the prevalence of aminoglycoside-modifying enzymes (AMEs) genes and the rate of resistance to amikacin, gentamicin, kanamycin and tobramycin a total of 1228 Staphylococcus aureus and 1004 S. epidermidis collected during 2009 from five Greek hospitals located in different geographic areas (Athens, Nothern and South-western Greece) were tested. Among S. aureus isolates, $48.2 \%$ carried any AMEs gene; $73.3 \%$ of the positive strains carried the $\operatorname{aph}\left(3^{\prime}\right)-I I I a$ gene, $13.7 \%$ the ant $\left(4^{\prime}\right)-I a$ and $13 \%$ the $\operatorname{aac}\left(6^{\prime}\right)-\operatorname{Ie}-\operatorname{aph}\left(2^{\prime \prime}\right)$ gene. The rate of resistance as determined by disk diffusion method and Etest was $48.2 \%$ for kanamycin, $48.2 \%$ for amikacin, $12.9 \%$ for tobramycin and $6.3 \%$ for gentamicin. MRSA were more resistant than MSSA (92.7\% resistant to amikacin and kanamycin, $25 \%$ to tobramycin and $12.3 \%$ to gentamicin versus $2.6 \%$ to amikacin and kanamycin and $0.3 \%$ to tobramycin respectively). Vitek 2 P549 card failed to characterize all S. aureus that carried the $\operatorname{aph}\left(3^{\prime}\right)$-IIIa gene. Significant differences on the rate of resistance and distribution of AME genes were observed among S. aureus strains originating in different hospitals. On the other hand, $42.8 \%$ of S. epidermidis, all methicillin-resistant, carried any AMEs genes; $70 \%$ of the positive strains carried the $a a c\left(6^{\prime}\right)-\operatorname{Ie}$-aph(2") gene in combination with both ant( $\left.4^{\prime}\right)-I a$ and $\operatorname{aph}\left(3^{\prime}\right)-I I I a$ genes, $18 \%$ carried the $a a c\left(6^{\prime}\right)-\operatorname{Ie}$-aph $\left(2^{\prime \prime}\right)$ gene with ant $\left(4^{\prime}\right)-I a$, while, $12 \%$ carried the $a a c\left(6^{\prime}\right)-I e-a p h\left(2^{\prime \prime}\right)$ gene with aph(3')-IIIa. The rate of resistance to all aminoglycosides tested was $42.8 \%$; $100 \%$ concordance of susceptibility results was observed between those of disk diffusion method, Etest and Vitek 2 P549 card. No significant differences on the rate of resistance or the AME gene distribution among different geographic regions were observed among S. epidermidis strains. These results suggest an alarming rate of aminoglycoside-resistant staphylococciin Greece and the necessity for a continuous surveillance.
\end{abstract}

Key words: aminoglycosides, S. aureus, S. epidermidis, Greece 


\section{Introduction}

Aminoglycosides are potent bactericidal agents that inhibit bacterial protein synthesis by binding to the $30 \mathrm{~S}$ ribosomal subunit. They are often used in combination with either beta-lactam or glycopeptides, especially for the treatment of complicated staphylococcal infections, as these drugs act synergically [1]. The main mechanism of aminoglycoside resistance in staphylococci is drug inactivation by cellular aminoglycoside-modifying enzymes (AMEs), which are categorized into four classes depending on the modifications they induce: acetyltransferases (AACs), phosphotransferases (APHs), nucleotidyltransferases (ANTS), and adenyltransferases (AADs). Among staphylococci, the most common AME is 6'-N-acetyltransferase-2"O-phosphotransferase [AAC(6')-APH(2")], encoded by the aac $\left(6^{\prime}\right)-\operatorname{Ie}-\operatorname{aph}\left(2^{\prime \prime}\right)$ gene inactivating gentamicin, kanamycin, tobramycin, neomycin, and amikacin. 4'-Oadenyltransferase I [ANT(4')-I] is encoded by ant(4')-Ia gene and inactivates kanamycin, neomycin, tobramycin and amikacin. Finally, 3'-O-phosphotransferase III [APH(3')-III] is encoded by $a p h\left(3^{\prime}\right)-I I I a$ and inactivates kanamycin and amikacin [2].

Despite the high incidence of aminoglycoside resistance among methicillinresistant staphylococci as reported before 2000, there is currently little information on the incidence and predominant types of AMEs in many countries. This lack of information is generally of great importance, particularly for Greece where, the prevalence of methicillin-resistant Staphylococcus aureus (MRSA) and methicillinresistant coagulase-negative staphylococci (MRCoNS) is high in correlation that, the last years, aminoglycosides and specifically amikacin and gentamicin are widely used in our clinical settings.

The aim of the present study is to provide information regarding the prevalence of AMEs in correlation with the rate of aminoglycoside-resistance among 
staphylococcal isolates collected from five different Greek hospitals during 2009, in order to define a baseline for monitoring possible future increase. 


\section{Materials and Methods}

\subsection{Bacterial isolates and study design}

During 2009, a total of 1228 Staphylococcus aureus [621 methicilin-resistant (MRSA) and 607 methicillin-sensitive (MSSA)] and 1004 Staphylococcus epidermidis [720 methicillin-resistant (MRSE) and 284 methicillin-sensitive (MSSE), representing approximately $80 \%$ of coagulase-negative staphylococci], were tested for their susceptibility to aminoglycosides. Isolates were recovered from clinically significant specimens (blood, pus, pleural fluid, etc) in five Greek tertiary care hospitals located in different areas of the country (Athens, Northern, South-western Greece). A single isolate per patient was included in the study. Identification of staphylococci was performed by the Vitek 2 Advanced Expert System (bioMerieux, Marcy l'Etoile, France). S. aureus ATCC 25923 and S. epidermidis ATCC 12228 were used as control strains for susceptibility testing. In addition, S. aureus BM 3002 [possessing ant(4')-Ia)] and Enterococcus faecalis BM 6217 [possessing aac(6')-Ie-aph(2") and $\left.a p h\left(3^{\prime}\right)-I I I a\right]$ served as positive controls for each resistance gene.

\subsection{Molecular methods}

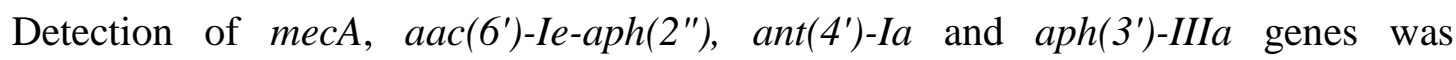
performed by the multiplex PCR protocol described by Choi et al [4]. Clones of representative MRSA and MRSE strains with different phenotypes and genotypes were defined by multi-locus sequence typing (MLST) ( http://www.mlst.net ).

\subsection{Susceptibility testing}

All isolates were tested for resistance to aminoglycosides by a disk diffusion method using amikacin $30 \mu \mathrm{g}$, gentamicin $10 \mu \mathrm{g}$, tobramycin $10 \mu \mathrm{g}$ and kanamycin $30 \mu \mathrm{g}$, 
according to the Clinical and Laboratory Standards Institute guidelines [3]. Determination of MICs to the above aminoglycosides was done by Etest (AB Biodisk, Solna, Sweden), as of the manufacturer's instructions. All isolates were also tested for their susceptibility to various antimicrobial agents by the use of the VITEK 2 P549 card.

\subsection{Statistical analysis}

The effects of distribution of AME genes and regions, as well as their interactions were examined using a log-linear model, and the significance levels of the individual comparisons (post-hoc tests) were adjusted using the Bonferroni's correction. The analysis was performed using GLIM3.77 (Royal Statistical Society). 


\section{Results}

According to PCR results, 592 S. aureus (48.2\%) carried any of the AMEs genes; 434 isolates, including 420 methicillin-resistant and 14 methicillin-sensitive, $(73.3 \%$ of PCR-positive) carried the $a p h\left(3^{\prime}\right)$-III $a$ gene, 81 isolates, including 79 methicillinresistant and 2 methicillin-sensitive, (13.7\% of PCR-positive) carried the ant( $\left.4^{\prime}\right)$-Ia gene, whereas, 77 isolates, all methicillin-resistant, (13\% of PCR-positive) carried the $\operatorname{aac}\left(6^{\prime}\right)-I e-\operatorname{aph}\left(2^{\prime \prime}\right)$. No coexistence of two or more AME genes was detected in any $S$. aureus strain. No direct correlation between sequence types (STs) and AME gene carriage was found. The great majority of ST80 and ST7 MRSA carried the $a p h\left(3^{\prime}\right)-I I I a$, while strains of ST239 (the main nosocomial clone), ST377 and ST225, carried either the ant $\left(4^{\prime}\right)-I a$ gene or the $\operatorname{aac}\left(6^{\prime}\right)-I e-a p h\left(2^{\prime \prime}\right)$ one. Strains of ST1 and ST30 did not carry any AME gene.

Susceptibility results based on disk diffusion method revealed that among 1228 S. aureus 636 isolates $(51.8 \%)$ were aminoglycoside-sensitive, whereas, the remaining 592 isolates (48.2\%) were resistant to any of the aminoglycosides tested; $48.2 \%$ were resistant to amikacin, $48.2 \%$ to kanamycin, $12.9 \%$ to tobramycin and $6.3 \%$ to gentamicin. Among MRSA tested, $92.7 \%$ exhibited resistance to amikacin, $92.7 \%$ to kanamycin, $25 \%$ to tobramycin and $12.3 \%$ to gentamicin. Among MSSA $2.6 \%$ exhibited resistance to amikacin, $2.6 \%$ to kanamycin and $0.3 \%$ to tobramycin. None of the aminoglycoside-resistant strains lacked any of the AMEs genes, while, a strong correlation between the resistant phenotypes and presence of AMEs genes was observed (100\% concordance). Results by Etest correlated well with those obtained by the disk diffusion method. However, discrepancies on susceptibility testing results of the automated VITEK 2 were observed: whereas the system identified correctly all 
S. aureus strains carrying the $a a c\left(6^{\prime}\right)-I e-a p h\left(2^{\prime \prime}\right)$ or ant $\left(4^{\prime}\right)$-Ia gene, it failed to detect stains possessing only the aph(3')-IIIa (Table 2).

An interesting finding was the significant differences observed on the distribution of AME genes among participating hospitals (Table 1). Overall, there is a significant AME gene effect $(\mathrm{P}<0.01)$ in terms of distribution, whereas, the regions differ significantly $(\mathrm{P}<0.01)$ in terms of resistance. The interaction between the AME gene distribution effect and region effect is also significant $(\mathrm{P}<0.01)$. More specifically, AME gene distribution effect follows different pattern across regions or the region effect varies across AME gene distribution. In particular, in South-western Greece all AME gene comparisons were significant $(\mathrm{P}<0.01)$. In Northern Greece the distribution of $a p h\left(3^{\prime}\right)$-IIIa gene was different from ant $\left(4^{\prime}\right)$-Ia gene and aac $\left(6^{\prime}\right)-I e-$ $\operatorname{aph}\left(2^{\prime \prime}\right) \quad(\mathrm{P}<0.01)$, whereas, the ant $\left(4^{\prime}\right)-I a$ gene was not different from aac $\left(6^{\prime}\right)-I e-$ $\operatorname{aph}\left(2^{\prime \prime}\right)(\mathrm{P}=0.27)$. In Athens, aph(3')-IIIa was marginally different from aac(6')-Ie$\operatorname{aph}\left(2^{\prime \prime}\right)(\mathrm{P}=0.04)$, whereas, the remaining comparisons were not significant [for $\operatorname{ant}\left(4^{\prime}\right)-I a$ vs aac $\left(6^{\prime}\right)-I e-\operatorname{aph}\left(2^{\prime \prime}\right), \mathrm{P}=0.30$, and for $\operatorname{aph}\left(3^{\prime}\right)-I I I a$ vs ant(4')-Ia, $\left.\mathrm{P}=0.29\right]$. Comparing the regions for each gene, South-western and Northern Greece are different from Athens $(\mathrm{P}<0.01)$ as far as aph $\left(3^{\prime}\right)-I I I a$, whereas, for South-western and Northern Greece are the same $(\mathrm{P}=0.99)$. For ant $\left(4^{\prime}\right)$-Ia, South-western Greece differ from Athens and Northern Greece $(\mathrm{P}<0.01)$, whereas, Northern Greece is not different from Athens $(\mathrm{P}=0.99)$. For $\operatorname{aac}\left(6^{\prime}\right)-I e-\operatorname{aph}\left(2^{\prime \prime}\right)$, there is a significant difference only between South-western and Northern Greece $(\mathrm{P}=0.02)$, whereas, Northern and Southwestern Greece are not different from Athens $(\mathrm{P}=0.26$ and 0.59 , respectively).

Among 1004 S. epidermidis 430 MRSE (42.8\%) carried at least two of AMEs genes. Among the positive isolates, $70 \%$ carried the $\operatorname{aac}\left(6^{\prime}\right)-\operatorname{Ie}-\operatorname{aph}\left(2^{\prime \prime}\right)$ gene in combination with both ant( $\left.4^{\prime}\right)-I a$ and $a p h\left(3^{\prime}\right)$-IIIa genes, $18 \%$ carried the aac $\left(6^{\prime}\right)-I e$ - 
$\operatorname{aph}\left(2^{\prime \prime}\right)$ gene with $\operatorname{ant}\left(4^{\prime}\right)-I a$, while, $12 \%$ carried the $\operatorname{aac}\left(6^{\prime}\right)-\operatorname{Ie}-\operatorname{aph}\left(2^{\prime \prime}\right)$ gene with aph(3')-IIIa. Even though the majority of aminoglycoside-resistant MRSE belonged to ST2 and ST22, the main clones in Greece, polyclonality was observed among resistant genotypes without any correlation of clones to AME gene carriage.

Susceptibility results based on disk diffusion method revealed that 430 isolates $(42.8 \%)$ were simultaneously resistant to all four aminoglycosides tested. All isolates were methicillin-resistant; no MSSE was detected with resistance to any aminoglycosides. Etest and VITEK 2 system identified correctly all aminoglycosideresistant isolates. No significant differences on the rate of resistance $(\mathrm{P}=0.54)$ or on AME gene distribution $(\mathrm{P}=0.29)$ among the regions were observed. 


\section{Discussion}

Although aminoglycosides retain activity against the majority of Gram-negative clinical bacterial isolates in many parts of the world, the relatively frequent occurrence of nephrotoxicity and ototoxicity during treatment make physicians reluctant to use these compounds in everyday practice [5]. The doubts regarding the actual clinical utility of aminoglycosides resulted to the use of other antimicrobial agents with improved safety [6]. However, the recent emergence of infections due to Gram-negative bacteria with advanced patterns of antimicrobial resistance has prompted physicians to reconsider these "old" antibacterial agents [7]. Aminoglycosides are also used in orthopaedic surgery, both locally and systemically, for prophylaxis of implant-related infections and treatment of skeletal infections. For local prophylaxis, application of gentamicin in the bone cement as well as coating of metallic implants with tobramycin or gentamicin appear to be effective, resulting in improved long-term implant survival [8]. For the treatment of skeletal infections, gentamicin-loaded bone cement beads, tobramycin impregnated beads and bone graft substitutes offer high concentrations of antibiotics at the site of infection [9]. However, local usage of aminoglycosides could rapidly induce antibiotic resistance among staphylococci with subsequent reduced effect on prophylaxis [10]. Since CoNS and $S$. aureus are the leading cause of device-related infections, continued surveillance concerning the resistance of staphylococci to aminoglycosides is required.

The rate of staphylococcal resistance to aminoglycosides varies from country to country and from year to year $[2,11,12,13]$. In a European multicenter study during 1999, Schmitz et al. reported that $23 \%, 29 \%$ and $31 \%$ of S. aureus were resistant to gentamicin, tobramycin and kanamycin, whereas, Hope et al. reported that $9 \%$ of MRSA and $2.5 \%$ of MSSA, collected from bacteraemia cases in UK and Ireland 
during 2001-2006, were resistant to gentamicin [2,11]. On the other hand, recent studies from Middle East showed a high incidence of aminoglycoside-resistant $S$. aureus $[12,13]$. In Greece, until now there was little information about the rates of aminoglycoside-resistant $S$. aureus. A previous study conducted in Central Greece during 2000 revealed that $11.2 \%$ and $18 \%$ of $S$. aureus exhibited resistance to gentamicin and tobramycin respectively [14]. Compared these results with our current data an inversion of the resistant phenotypes is observed, with a decrease of gentamicin and tobramycin-resistance (6.3\% and $12.9 \%$ respectively) followed by a significant increase of kanamycin and amikacin resistance $(48.2 \%$ for both agents versus $29.2 \%$ in 2000), partially due to the predominance of ST80 MRSA clone in the country $[14,15]$. In addition, in contrast to other studies, the $\operatorname{aph}\left(3^{\prime}\right)-I I I a$ was the most prevalent AMEs gene $(73.3 \%)$ in our strains $[2,12,13]$. The significant differences on the resistance rate and AME gene distribution of $S$. aureus among Greek regions may be due to the predominance of specific clones and to aminoglycoside usage in each clinical setting combined with a possible horizontal AME gene transfer, as reflected in the results of participating hospitals.

Concerning the rate of aminoglycoside-resistant CoNS previous studies showed that were more often aminoglycoside-resistant than S. aureus [2,11]. In Greece, while $31 \%$ and $35 \%$ of $S$. epidermidis were resistant to gentamicin and tobramycin respectively during 2000 , a significant increase of resistance ( $42.8 \%$ to both agents) is observed in S. epidermidis isolates eight years latter $[14,16]$. All isolates carried at least two AMEs genes. Indeed, CoNS have been frequently been reported to carry resistance determinants, including genes encoding AMEs and as such have the capacity to function as genetic reservoir. Conjugal transfer of resistance determinants 
between $S$. aureus and $S$. epidermidis leads to rapid dissemination of these determinants in the hospital environment.

As previously mentioned, VITEK 2 failed to detect kanamycin and amikacin resistance among $S$. aureus isolates carrying the aph(3')-IIIa gene. This can be explained by the fact that kanamycin and amikacin, that are accurate indicators of aph(3')-IIIa gene presence, were not included in P549 card; unfortunately, the newer P490 card also does not include them. Misidentification of such strains may lead to a therapeutic failure in cases where kanamycin or amikacin are used. On the contrary, VITEK 2 correctly identified aminoglycoside-resistant phenotypes among $S$. epidermidis, since all resistant S. epidermidis carried at least the aac(6')-Ie-aph(2") gene, and thus, exhibited resistance to gentamicin and tobramycin that are included in the P549 card. Thus, we recommend that laboratories using VITEK should employ alternative susceptibility testing methods for the detection of kanamycin and amikacin resistance in S. aureus.

In conclusion, this is the first study that describes the distribution of AME genes in correlation with the rate of aminoglycoside-resistant staphylococci in Greece during one year period (2009), providing useful comparative data for future studies. Today, according to hospital pharmacy records, amikacin and gentamicin are widely used in our clinical settings, specifically in those, where the prevalence of KPC-producer gentamicin-sensitive K. pneumoniae is high [7]. Probably, the re-introduction of these aminoglycosides in the clinical practice may enhance the emergence and dissemination of staphylococcal clones resistant to these agents. The high rate of aminoglycoside-resistant staphylococci (48.2\% S. aureus and $42.8 \%$ S. epidermidis) in Greek hospitals located at different areas of the country indicates the need of accurate detection of resistance combined with knowledge of the epidemiology of 
such resistance determinants, in order to limit further increase and to preserve the usefulness of aminoglycosides in the treatment of complicated infections. 


\section{References}

1. Lowy FD. (1998) Staphylococcus aureus infections N. Engl J Med . 339(8):52032

2. Shmitz FJ, Fluit AC, Gondolf M, Beyrau R, Lindenlauf E, Verhoef J, Heinz HP, Jones ME. (1999) The prevalence of aminoglycoside resistance and corresponding resistance genes in clinical isolates of staphylococci from 19 European hospitals. J Antimicrob Chemother. 43(2):253-9

3. Choi SM, Kim SH, Kim HJ, Lee DG, Choi JH, Yoo JH, Kang JH, Shin WS, Kang MW. (2003) Multiplex PCR for the detection of genes encoding aminoglycoside modifying enzymes and methicillin resistance among Staphylococcus species. J Korean Med Sci. 18(5):631-6

4. Clinical and Laboratory Standards Institute. (2009) Performance Standards for Antimicrobial Susceptibility Testing: Nineteenth Informational Supplement M100-S19. CLSI. Wayne, PA, USA,

5. Durante-Mangoni E, Grammatikos A, Utili R, Falagas ME. Do we still need the aminoglycosides? (2009) Int J Antimicrob Agents. 33(3):201-5

6. Karageorgopoulos DE, Falagas ME. (2009) New antibiotics: optimal use in current clinical practice. Int J Antimicrob Agents. 34 Suppl 4:S55-62

7. Giakoupi P, Maltezou H, Polemis M, Pappa O, Saroglou G, Vatopoulos A; Greek System for the Surveillance of Antimicrobial Resistance. (2009) KPC-2-producing Klebsiella pneumoniae infections in Greek hospitals are mainly due to a hyperepidemic clone. Euro Surveill. 14 (21)

8. Lucke M, Schmidmaier G, Sadoni S, Wildemann B, Schiller R, Haas NP, Raschke M. (2003) Gentamicin coating of metallic implants reduces implant-related osteomyelitis in rats. Bone. 32(5):521-31. 
9. Rasyid HN, van der Mei HC, Frijlink HW, Soegijoko S, van Horn JR, Busscher HJ,Neut D. (2009) Concepts for increasing gentamicin release from handmade bone cement beads. Acta Orthop. 80(5):508-13

10. Anguita-Alonso P, Hanssen AD, Osmon DR, Trampuz A, Steckelberg JM, Patel R. (2005) High rate of aminoglycoside resistance among staphylococci causing prosthetic joint infection. Clin Orthop Relat Res. 439:43-7

11. Hope R, Livermore DM, Brick G, Lillie M, Reynolds R; BSAC Working Parties on Resistance Surveillance. (2008) Non-susceptibility trends among staphylococci from bacteraemias in the UK and Ireland, 2001-06. J Antimicrob Chemother. 62 Suppl 2:ii65-74

12. Emaneini M, Taherikalani M, Eslampour MA, Sedaghat H, Aligholi M, Jabalameli F, Shahsavan S, Sotoudeh N. (2009) Phenotypic and genotypic evaluation of aminoglycoside resistance in clinical isolates of staphylococci in Tehran, Iran. Microb Drug Resist. 15(2):129-32

13. Yadegar A, Sattari M, Mozafari NA, Goudarzi. (2009) Prevalence of the genes encoding aminoglycoside-modifying enzymes and methicillin resistance among clinical isolates of Staphylococcus aureus in Tehran, Iran. Microb Drug Resist.15(2):109-13

14. Petinaki E, Miriagou V, Tzouvelekis LS, Pournaras S, Hatzi F, Kontos F, Maniati M, Maniatis AN; Bacterial Resistance Study Group of Thessaly. (2001) Methicillinresistant Staphylococcus aureus in the hospitals of central Greece. Int J Antimicrob Agents.18(1):61-5

15. Chini V, Petinaki E, Meugnier H, Foka A, Bes M, Etienne J, Dimitracopoulos G and Spiliopoulou I. (2008) Emergence of a new clone carrying Panton-Valentine 
leukocidin genes and Staphylococcal Cassette Chromosome mec type V among methicillin-resistant Staphylococcus aureus in Greece. Scan J Infect Dis. 40: 368-372. 16. Petinaki E, Kontos F, Miriagou V, Maniati M, Hatzi F, Maniatis AN; Bacterial Resistance Study Group. (2001) Survey of methicillin-resistant coagulase-negative staphylococci in the hospitals of central Greece. Int J Antimicrob Agents. 18(6):563-6 
Table 1. Distribution of AME genes among S. aureus isolates collected from three regions of Greece: South-western Greece (A), Northern Greece (B) and Athens (C).

\begin{tabular}{cccccc}
\hline Region & Total No & \multicolumn{3}{c}{ AMEs genes distribution } & No of AME- \\
& of & aph(3')-IIIa & ant(4')-Ia & aac(6')-Ie-aph(2") & positive \\
& isolates & No (\%) & No $(\%)$ & No $(\%)$ & isolates \\
& & & & No (\%) \\
A & 517 & $196(38)$ & $12(2.3)$ & $22(4.3)$ & $230(44.5)$ \\
B & 577 & $219(38)$ & $57(10)$ & $46(8)$ & $322(55.8)$ \\
C & 134 & $19(14.2)$ & $12(8.9)$ & $9(6.7)$ & $40(29.9)$ \\
\hline Total & 1228 & $434(35.3)$ & $81(6.6)$ & $77(6.3)$ & $592(48.2)$ \\
\hline
\end{tabular}


1 Table 2. Comparison of susceptibility results based on Disk Diffusion method (DD), Etest, Vitek 2 P549 card (VT) and sensitivity of each 2 method, towards the respective genotypes of S. aureus.

\begin{tabular}{|c|c|c|c|c|c|c|c|}
\hline \multicolumn{2}{|c|}{ Genotypes } & \multicolumn{2}{|c|}{ DD } & \multicolumn{2}{|c|}{ Etest } & \multicolumn{2}{|c|}{ VT } \\
\hline Gene & $\begin{array}{c}\text { Positive isolates } \\
\text { (number) }\end{array}$ & $\begin{array}{l}\text { Resistant } \\
\text { (number) }\end{array}$ & $\begin{array}{c}\text { Sensitivity } \\
(\%)\end{array}$ & $\begin{array}{l}\text { Resistant } \\
\text { (number) }\end{array}$ & $\begin{array}{c}\text { Sensitivity } \\
(\%)\end{array}$ & $\begin{array}{l}\text { Resistant } \\
\text { (number) }\end{array}$ & $\begin{array}{c}\text { Sensitivity } \\
(\%)\end{array}$ \\
\hline$a p h\left(3^{\prime}\right)-I I I a$ & 434 & 434 & $100 \%$ & 434 & $100 \%$ & 0 & - \\
\hline $\operatorname{ant}\left(4^{\prime}\right)-I a$ & 81 & 81 & $100 \%$ & 81 & $100 \%$ & 81 & $100 \%$ \\
\hline $\operatorname{aac}\left(6^{\prime}\right)-\operatorname{Ie}-\operatorname{aph}\left(2^{\prime \prime}\right)$ & 77 & 77 & $100 \%$ & 77 & $100 \%$ & 77 & $100 \%$ \\
\hline Total & 592 & 592 & $100 \%$ & 592 & $100 \%$ & 158 & $26.7 \%$ \\
\hline
\end{tabular}

3

4 